\title{
Oil Price and Exchange Rate Nexus-Evidence From Nigeria
}

\author{
Dauda Mohammed (Corresponding author) \\ Monetary Policy Department, Central Bank of Nigeria, Nigeria \\ Tel: 234-8130-124-907Ｅ-mail: daudaknt@yahoo.co.uk
}

Udoma J. Afangideh

Central Business District, Garki, Abuja, Nigeria

Tel: 234-8030-780-559

Oloruntoba S. Ogundele

Central Business District, Garki, Abuja, Nigeria

Tel: 234-8124-662-505

Received: December 25, 2018 Accepted: February 6, 2019 Published: February 21, 2019

doi:10.5296/ijafr.v9i1.14386

URL: https://doi.org/10.5296/ijafr.v9i1.14386

\begin{abstract}
Price swings at international crude oil market significantly impact on macroeconomic fundamentals of oil dependent countries. Hence, understanding the relationship between oil price movement and the exchange rate has become imperative especially for oil exporting countries. This paper examines the causal effect between oil prices and Nigerian naira-US dollar exchange rate using frequency daily data for the period 12/07/2010-31/08/2017. Generalized autoregressive conditional heteroskedasticity (GARCH) and exponential GARCH (EGARCH) models were used to estimate our oil prices and nominal naira exchange rate equation. Our findings reveal a positive relation between oil price and naira exchange rate meaning that an upward movement in the price of oil causes the naira to depreciate. Conversely, any fall in oil price leads to appreciation in the value of the naira. The result has important policy implication given that $90 \%$ of the total annual foreign revenue of Nigeria comes from oil thus oil price shocks have severe impact on the Nigerian economy. This
\end{abstract}


justifies the need for Nigeria's economic diversification to minimize the vulnerability of the Nigerian economy to vagaries of the international crude oil market and to delink the exchange rate and reserve movement from developments in oil prices.

Keywords: Oil price, Exchange rate, Volatility, GARCH/EGARCH, Nigeria

JEL Classifications: F31, E52

\section{Introduction}

Crude oil export has become the mainstay of many underdeveloped economies, following the discovery of huge deposits of petroleum around the world with its concomitant potentials for generating national wealth. However, disruptions in economic activities owing to vagaries of international crude oil market have become regular episodes in the global economy thus affecting the economic prosperity of oil income dependent countries. This has also led to both theoretical and empirical debates on the exact relationship between oil price and exchange rate. The main argument for the oil price- exchange rate volatility transmission is based on the fact that oil is quoted in US dollars (USD) and, therefore, variations in oil price do shape exchange rate behavior of trading countries through the reference currency which is the US dollar. Krugman (1983) and Golub (1983) argue that higher oil prices will transfer wealth from the oil importers to oil exporters. This means that when oil price rises, oil exporting countries may experience an appreciation of their exchange rate and oil importing countries experience a depreciation of their exchange rate. However, if the oil importer constitutes a small share of the oil export market but a larger share of the oil exporter's imports, then the transfer of wealth from oil importers to oil exporters would improve the oil importers' trade balance, which would mean that the long-run effect on the exchange rate is positive for the oil importers (Corden, 1984; De Grauwe, 1996).

Given that crude oil is a critical driver of the world economy, changes in its price would mostly affect the economy and welfare of citizen of many countries particularly Nigeria, which is a major oil exporting country. The country is ranked as Africa's largest producer of crude oil and one of the world leading oil producers as well as net exporter of oil. For instance, about $90 \%$ of the total annual foreign revenue of Nigeria comes from oil hence; changes in oil price have severe implications on Nigerian macro economy.

As expected, the Nigerian economy has over time being affected by oil price shocks at different time forcing the country to take critical fiscal and monetary decision to stem the effect of the shocks. Most recently, in the period 2010-2016, crude oil price fell from about US $\$ 147$ per barrel to less than US\$30 and this weakened the economy as the rate of growth in the economy begins to decline slowly from 8.6 per cent in the fourth quarter of 2010 to 2.1 per cent in the last quarter of 2015. For instance core inflation averaged 9.4 percent between 2007 and 2015 and increased to 12.8 percent in March, 2016 and currently 15.9 per cent. The nominal exchange rate also depreciated - from a value of N155/US\$1 in 2010 to N199/US\$1 while the parallel market rate hovers around N340 -500/US\$1 in 2015. Consequently, the $\mathrm{CBN}$ has to intervene to save the naira from further depreciation by closing the entire official widow in the later part of 2015. This was replaced with the Flexible Exchange Rate 
Inter-bank Market where the naira trade at N305/\$1 suggesting a sort of managed float regime. From the above analysis we can clearly observed that as Nigeria's major foreign exchange earner, any fall in oil price also affects its foreign reserves. This is because excessive demand for the dollar often compelled the Nigerian monetary authorities to periodically intervene and ensure liquidity in the market in order to save the local currency. For instance, Nigeria's foreign reserves declined from US\$62 billion in 2007 to about US\$28 billion as at March 2016. The recent surge in oil prices in the period of 2017 and 2018 when oil price averaged at US\$53 and $\$ 57$ saw the Nigeria's foreign reserve rising to US\$43.2 and continue to hover around that value.

The scenario of the impact of oil price on Nigeria as painted above provide the main justification for our empirical study of oil-price/Nigeria exchange rate nexus. As oil dependent nation, constant empirical investigation into the nexus between oil price and USNigeria exchange rate will provide a guidepost for both fiscal and monetary (the CBN) policy formulation. Therefore, the study would also be valuable to similar jurisdictions especially the oil exporting economies with high dependent on oil receipts as their major source of revenue.

Following the work of Narayan and Prasad (2008), the study seeks to examine how changes in oil price impact on Nigeria's naira exchange rate with respect to the US dollar. We utilized daily data for the period 12/07/2010-31/08/2017. Generalized autoregressive conditional heteroskedasticity $(\mathrm{GARCH})$ and exponential GARCH $(\mathrm{EGARCH})$ were used in explaining the linkage. The paper is organized into eight sections as highlighted hereunder. Section two reviews related literature. Section three provides an overview of Exchange Rate Regimes in Nigeria, Section four explains the model while Section five describes the Data and its characteristics. Section six provides pre-estimation tests and section seven tabulates and analyses the results while the final section eight discusses the results and concludes the paper.

\section{Review of Literature}

A number of authors had provided various insights on the link between oil prices at the international market and economic variables of oil exporting countries. As mentioned earlier the pioneering works on the linkage between oil price and exchange rate is traceable to the following researcher including; Hamilton (1983), Golub (1983), and Krugman (1983) Gisser \& Goodwin (1986), and Mork (1989). Hooker (1996), Cunado and Perez de Garcia (2005), and Kilian (2008) consolidated on the theory by examining how oil price shocks impact on economic factors such as economic downturns, inflation and growth, in both the developing and industrialized nations. The impacts of oil price volatility have been found to manifest in different ways and through different mechanisms as supported in some empirical studies (Hamilton, 2003; Zhang, 2008; Cologni and Manera, 2008). A study of oil price shocks and stock market reaction by Jones and Kaul (1996) found evidence of significant impacts of oil price changes on stock market returns in US as well as Canada while the results were inconclusive in the case of Japan and the UK.

Similarly, Park and Ratti (2008) studied the effect of oil price shocks, stock markets earnings in USA and some European countries using the Vector Autoregressive (VAR). They 
indicated strong impact of oil price swing on stock market earnings in the sampled countries except the USA. Equally, but using the unrestricted VAR model, Huang et al. (1996) study on the impact of oil price and stock returns of selected American oil companies did not reveal any correlation between oil prices and market indices. In similar fashion, Sadorsky (1999) also found asymmetric connection between oil price and economic activities.

Following the same pattern, Afees and Mobolaji (2013) employed VAR and the GARCH models to explain the effects spillovers on stock returns in Nigeria and the effects of oil price movement on naira-dollar exchange rates. Their findings highlighted the importance of hedging oil price and foreign exchange rate in Nigeria. They concluded that the inclusion of oil into a diversified portfolio of FX would improve its risk factor. On their part, Narayan and Prasad (2008) used the two components of generalized conditional heteroskedasticity model to examine the linkage between oil prices and Fiji-US exchange rate. They found that any uptick in the movement of oil price will cause the Fijian dollar to appreciate against the US dollar. El-Shariff et al (2005) study showed a positive relation between stock returns and increase in price by UK oil companies in consistence with Boyer and Filion (2007) study on Canada.

Similarly, Arouri, Bellalah and Nguyen (2011) also show that causality generally runs from oil prices to stock markets. In the same vein, Malik and Hammoudeh (2005) used multivariate GARCH model to examine oil price volatility and US stock and found significant effect of volatility in US equity and in the global oil markets. They also found that oil market volatility significantly affects the Gulf equity markets of Bahrain, Kuwait and Saudi Arabia. Using generalized VAR-GARCH approach Arouri, Jouini and Nguyen (2012) study the effects of oil swing on stock market returns in some European countries and the US. The result show that transmission of oil price volatility to stock markets moves in one direction in Europe while it flows in both ways in the United States. More recent studies have focused on the interaction between oil prices and exchange rates. Zhang's (2013) study re-examined previous works on the extent of relationship between the US dollar and oil price using the cointegration technique on the US monthly data. He found a stable relationship between both variables though not significant, except for two periods where the data were controlled for structural breaks. Fratszcher et al (2014) employed causality analysis for oil prices and the US dollar using multifactor model and established a bidirectional causality between the two variables.

Basher et al (2012) utilize the structural vector autoregression (SVAR) technique to investigate the dynamic relationship between real oil prices, exchange rate index of major currencies, emerging market stock prices, interest rates, global real economic activity and oil supply. The estimated empirical results show that the six-variable SVAR model fits the data well in supporting some stylized facts. In particular, they found that a positive shocks to oil prices tend to depress emerging market stock prices and US dollar exchange rates in the short run. Also a positive oil production shock lowers oil prices while a positive shock to real economic activity increases oil prices and thus concluded that increases in emerging market stock prices often led to rise in oil prices 
Hamisu, et al (2015) used Engle-Granger technique, threshold autoregressive (TAR) and momentum threshold autoregressive (MTAR) models to investigate the correlation that exists between the South African rand (ZAR) and oil prices for a period of 43 years. They found long run causality between oil price and exchange rate variables. In the same vein, Kin and Courage (2014) investigated the effects that oil prices on ZAR, this time, applying the Generalized Autoregressive Conditional Heteroskedasticity (GARCH) technique on South Africa's monthly data. The results showed that the ZAR exchange rate was significantly affected by changes in oil price at the international oil market. Kaushik et al (2014) researched on impact of changes in oil price using the error correction technique to analyze 15-year quarterly data of Indian rupee - US dollar real exchange rate. Their results did not show significant impact on the USD-IR exchange rate by oil price changes. On his part, Akram's (2002) study adopted the Error Correction Model with different specifications for symmetry and asymmetry to study the impact of oil price shock on Norwegian krone. The result showed a negative relationship between oil prices and krone.

In the same vein, Beckmann et al (2017) reviews existing theoretical and empirical research on the relationship between oil prices and exchange rate. The theoretical model suggests a bi-directional causality transmission channels. On its part, empirical research examined the forecasting aspect and found that the relationship varies substantially depending on sample, country choice and the method adopted. Also, Kim and Jung (2018) investigates the relationship between daily crude oil prices and exchange rates using functional data analysis showing the clustering pattern of exchange rates and oil prices over the time period. They found evidence of significant positive relationship in all the pairs, except for the Mexican peso-Brent. In particular, they showed that rise in the West Texas Intermediate (WTI) oil price returns is associated with depreciation of the US dollar.

In Nigeria, Ogundipe et al (2014) estimated a long run relationship and speed of adjustments on the naira exchange rate with respect to changes in the oil price, applying the often used Johansen cointegration and Vector Error Correction (VEC) techniques. They found that more-than-proportionate change in the exchange rate responds to a change in oil price thus, confirming the vulnerability of the Nigerian economy to vagaries of the international oil market. Similarly, Oriavwote and Eriemo (2012) applied the cointegration, granger causality and GARCH methods on oil price volatility and exchange rate in Nigeria covering a period of 30 years. They established the presence of a long run relationship and persistence of volatility between the two variables. Overall, the studies above contributed greatly to the understanding of impact of oil price volatility on exchange rate.

\section{Overview of Exchange Rate Regimes in Nigeria}

Management of the exchange rate in Nigeria is one of the core mandates of the Central Bank of Nigeria. The country's exchange rate management has transited through various regimes for instance, the country has moved from a peg regime to a flexible exchange rate regime. This follows the adoption of structural adjustment policy in 1986 when countries including the underdeveloped ones were persuaded by the IMF to put the market mechanism at the heart of economic policies. This led to the privatization of state enterprises and other assets 
and Nigeria wholly accepted the new order and enshrines it recommended measures. These include the privatization of key institutions including telecommunication, financial institutions, education, health and free-floating exchange rates among several other structural adjustments. This marked Nigeria's journey to a floating exchange rate regime which saw country devaluing its currency by $49.7 \%$ to the tune of $4.02 / \$ 1$ and subsequently oscillates to various regimes from fixed, float to managed float depending on the magnitude of oil shocks.

It is generally recognized that both empirically and in practice, no exchange rate regime fit all countries hence it is subject to the peculiarities of each country, the dynamics of global economies and that of its trading partners. Given this understanding Nigeria alternated between pegged regime in the 1960s and 70s to Dutch Auction System (DAS) in the aftermath of the Structural Adjustment period in 1987 to Interbank Foreign Exchange Market (IFEM) in 1989. It also went on to introduce the Autonomous Foreign Exchange (AFEM), the Wholesale Dutch Auction System (wDAS) in 2006/2007 before moving to Retail Dutch Auction System (rDAS) in 2013. The Bank finally shut down all the official exchange rate widows in 2015 and replaced it with Flexible Exchange Rate Inter-bank Market. It is expected to operate as a single market structure through the inter-bank/autonomous window. Similarly, the Exchange Rate would be purely market-driven using the Thomson-Reuters Order Matching System as well as the Conversational Dealing Book while the CBN participate through periodic interventions to either buy or sell FX as the need arises.

\section{The Model - Conditional Volatility of Oil Price and Naira - US Exchange Rate}

We employ a two-steps approach in modeling the framework for oil price and Nigerian naira-US dollar exchange rate. In the first phase, two variables are specified, precisely Brent crude oil price and naira exchange rate, both are converted in return form by taking the log difference and expressed as percentages. The nominal oil price is expressed in US dollar price while the nominal exchange rate is expressed in terms of the naira which is the local currency. This means that an increase in the exchange rate means depreciation of the naira and vice visa.

The consideration of the relationship between nominal variables is because daily tracking of the behavior of exchange rate and oil price does not need our understanding of real values. Thus, it becomes unimportant to consider the long run relationship among the variables as we have considered the daily behavior as nominal value movement. We also share the view that any decision based on long run relationship should consider real values. As in the case of other authors (Narayan et al 2008), we rule out the possible examination of relationship that exists between real value exchange rate and oil price.

Hence, our computation of daily returns is as follows:

$$
\operatorname{roil}_{\mathrm{t}}=\log \left(\frac{\operatorname{oil}_{\mathrm{t}}}{\operatorname{Oil}_{\mathrm{t}-1}}\right)
$$




$$
\operatorname{rexch} t=\log \left(\frac{\operatorname{exch}_{t}}{\operatorname{exch} t-1}\right)
$$

Where roil represents the returns on oil prices while rexch represents the nominal exchange rate returns.

An examination of the relationship between exchange rate and oil price was carried out using GARCH (p.q) and EGARCH (p.q) models. Following Narayan et al (2008), Bollerslev (1986) and Nelson (1991), a joint estimate of a conditional mean and conditional variance equations is carried out. Estimating the returns of each series ensures that each of them is stationary as confirmed by our test of stationarity. The form of the mean equation for both models is as follows:

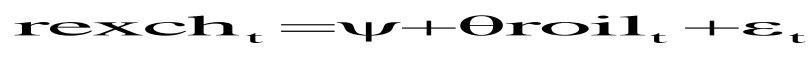

Another mean (GARCH-M) equation that includes GARCH is considered as follows:

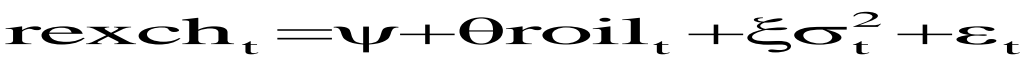

The variance equation of the GARCH and GARCH-M models is presented below:

$$
\sigma_{t}^{2}=\omega+\alpha_{1} \varepsilon_{t-p}^{2}+\alpha_{2} \sigma_{t-q}^{2}
$$

The variance equation for the EGARCH and the EGARCH-M are modeled as follows:

$$
\log \left(\sigma_{t}^{2}\right)=\omega+\alpha\left(\left|\frac{\varepsilon_{t-p}}{\sigma_{t-p}}\right|-\sqrt{\frac{2}{\pi}}\right)+\gamma \frac{\varepsilon_{t-1}}{\sigma_{t-1}}+\beta \log \left(\sigma_{t-q}^{2}\right)
$$

The above EGARCH model specification (6) allows for forward and backward behavior in the conditional variance as the parameter $\beta$ can be positive or negative. Nelson (1991), $|\beta|<1$ confirms stationarity and ergodicity for the EGARCH (p,q) in evaluating the persistence of shocks as a result of the estimation of $\beta$. We also use the parameter $\gamma$ in order to examine asymmetric or symmetric effects of volatility in the model. Thus, a positive sign of the gamma indicates that the presence of a positive change may result in greater volatility compared to negative shocks.

The degree of conditional shock on the variance is measured by the parameter $\alpha$ while $\psi$ is a constant term. We used the Bollerslev and Wooldridge (1992) approach to achieve robust conclusion of the estimated models. Our estimated equation applied the optimal maximum likelihood estimation approach of $p$ and $q$ lag lengths that is rooted in Schwartz Bayesian 


\section{MInstitute ${ }^{\text {Mit }}$}

(SBC, Schwartz, 1978) criterion with the assumption of normally distributed errors. The following section provide information about the data and some descriptive statistics of the two series.

\section{Data}

\subsection{Characteristics of the Data}

The data consists of daily oil price and naira exchange rate sourced from Blomberg and covered the period of 12/07/2010 - 31/08/2017. Trends in nominal exchange rate and oil price data along with their returns are presented Figures I and II below. Both graphs indicate evidence of volatility clustering; that is, periods of high volatility are followed by times of serenity and there is also evidence of structural breaks in the series. On the other hand, figure III shows the combined trends in exchange rate and oil price data. The graphical representation seems to suggest that the exchange rate and oil price markets move in opposite direction. For instance, exchange rate peaked in the period of falling oil prices thus signifying a depreciation of the naira.

As mentioned earlier the bulk of the Nigerian foreign exchange earnings comes from oil hence any shock in oil price would affect the revenue profile of the country and thus make exchange rate management difficult for the central Bank. For example, as highlighted in figure III (the last exchange rate before devaluation) coincide with the period of falling oil price. Thus it became more difficult for the monetary authority (CBN) to defend the naira. For example, the Nigerian exchange rate market experience serious scarcity of the dollar when the naira was official pegged at N197/US\$, making the naira/\$ to exchange at more than $100 \%$ at the parallel market. This compel the country to devalue the naira by $53.6 \%$ exchanging at N320/US\$ at the official interbank market. Similarly, figure IV and V indicate clustering in the returns of the series meaning that both series exhibit volatility however; the volatility clustering in oil price appears to be slightly more than that of the exchange rate series. Similarly, the volatility clustering supports the observed higher standard deviation of the oil price sequence.

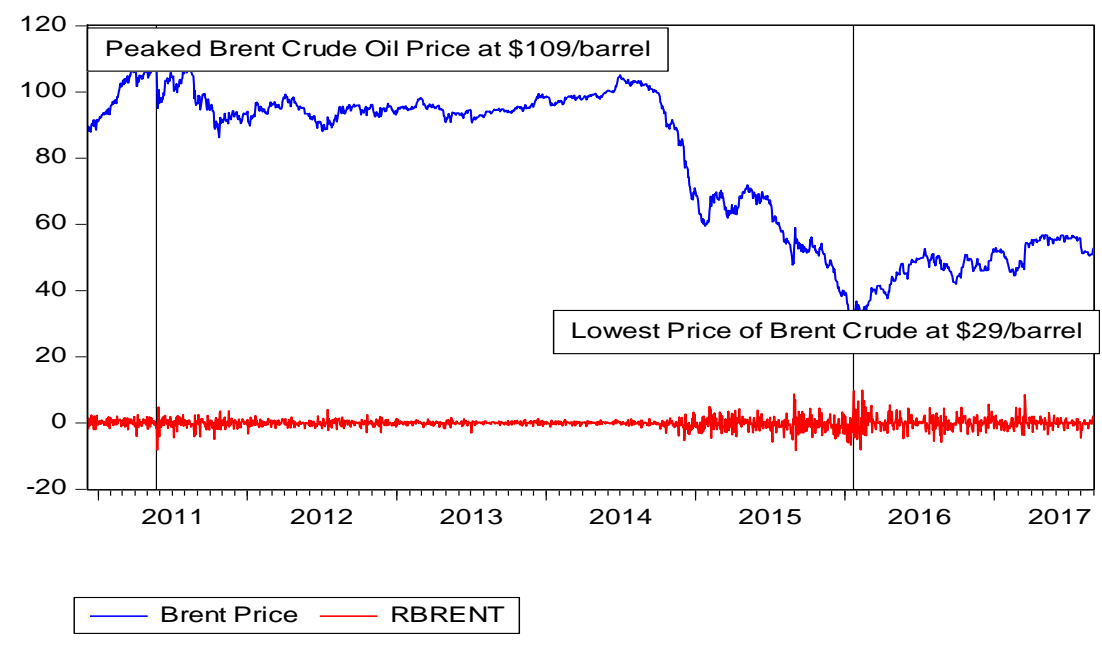


Figure 1. Trend in Brent - crude oil price and its return 2010 - 2017

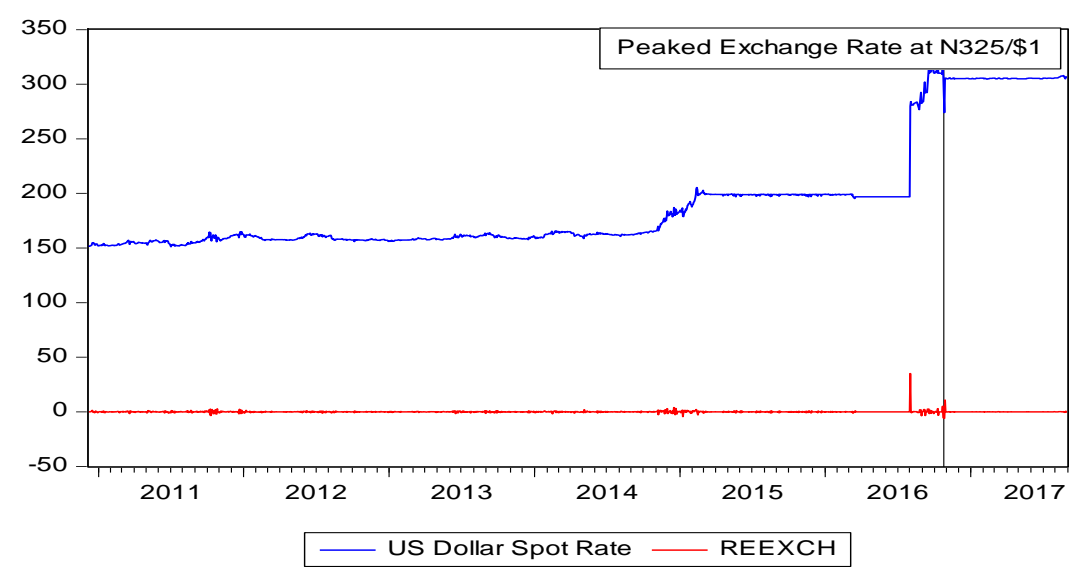

Figure 2. Trend in Naira to dollar exchange rate and its return 2010 - 2017

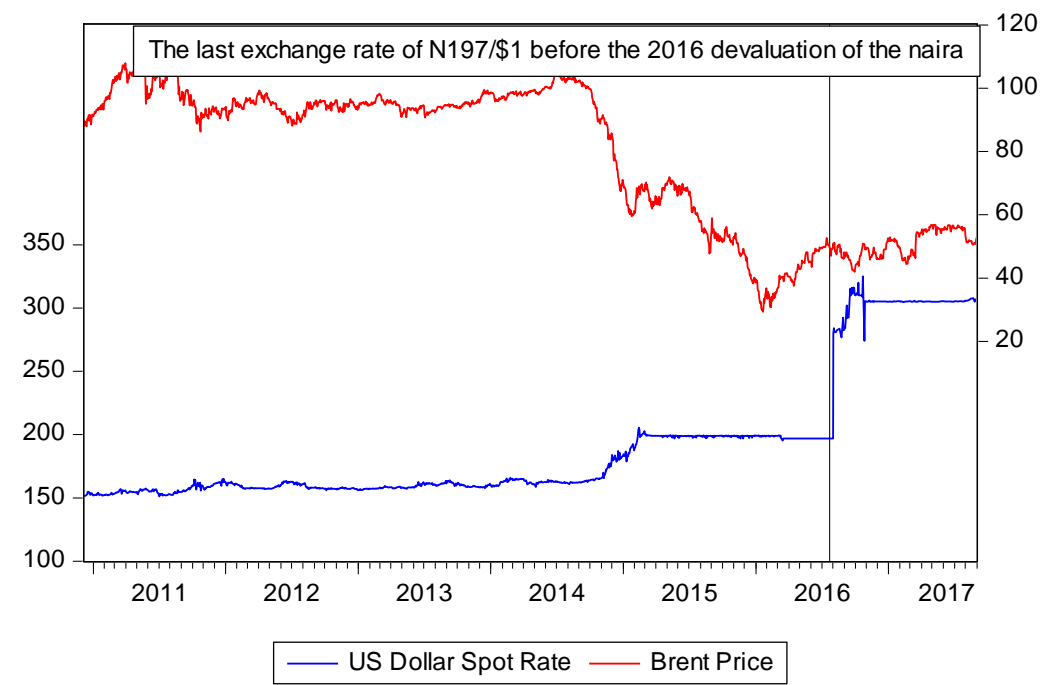

Figure 3. Combined in exchange rate and oil price data

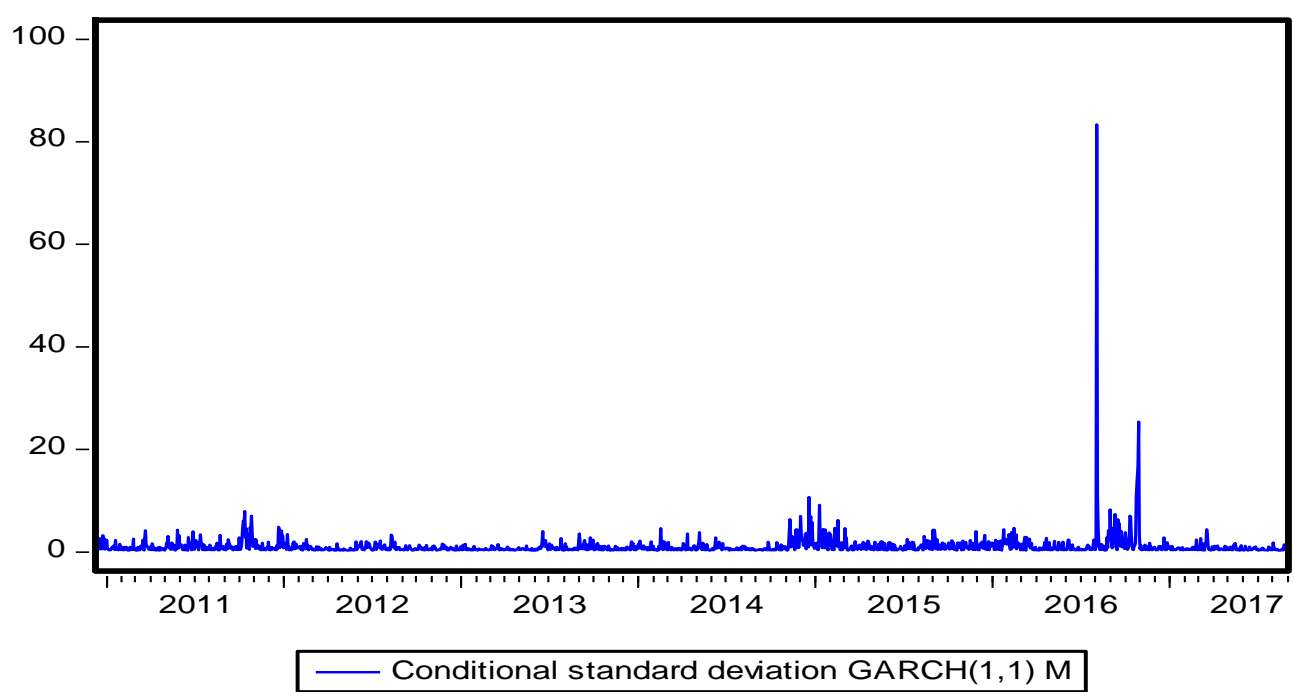


Figure 4. Conditional standard deviation $\operatorname{GARCH}(1,1) \mathrm{M}$

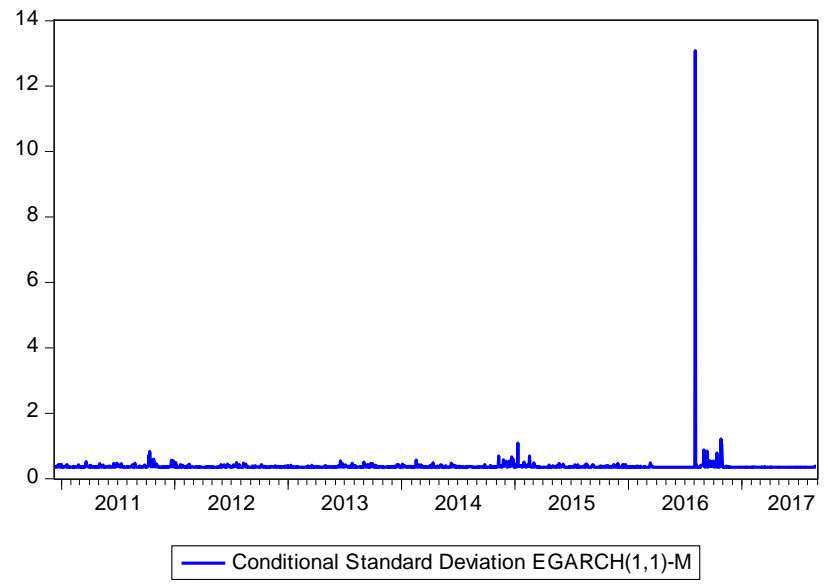

Figure 5. Conditional standard deviation EGARCH $(1,1)-\mathrm{M}$

The quantile-quantile plot of the two series in Figure VI signify that both series share similar distribution.

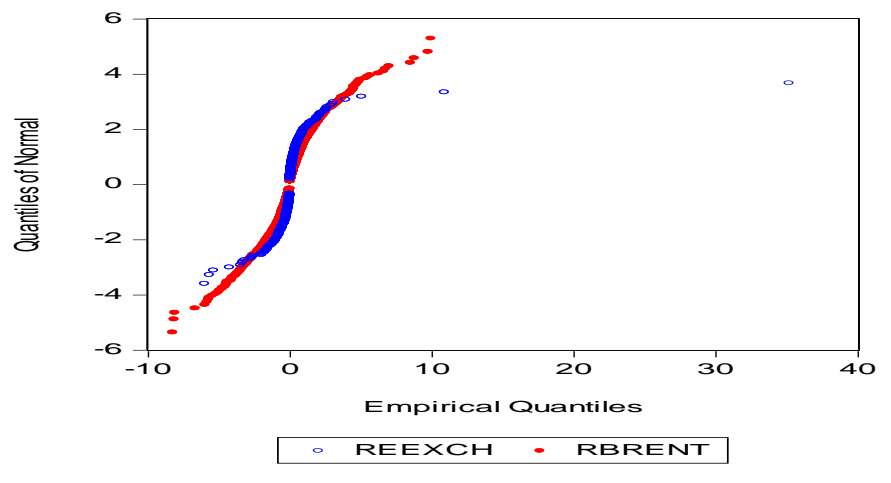

Figure 6. The quantile-quantile plot

\subsection{Pre-estimation Tests}

We also provide relevant descriptive statistics and formal pre-tests in order to evaluate the statistical properties of the series which include the mean, standard deviation and the distribution properties on the basis of skewness and kurtosis. These are presented in table 1 below.

Table 1. Descriptive statistics

\begin{tabular}{lll}
\hline & Roil & Rexch \\
\hline Mean & -0.030 & 0.040 \\
\hline Standard deviation & 1.545 & 1.055 \\
\hline
\end{tabular}




\begin{tabular}{lll} 
Skewness & 0.244 & 21.373 \\
\hline Kurtosis & 9.221 & 708.481 \\
\hline Jarque-Bera & 2850.526 & 3656.980 \\
& $(0.0000)$ & $(0.0000)$
\end{tabular}

The mean values reported in the summary statistics indicate negative average returns in the oil markets for the period under study thus suggesting that the returns on oil prices have not bounced from the global oil crash. Similarly, the descriptive statistics in the table shows that the mean of exchange rate series is higher than that of the oil price series. The dispersion in the oil return series is higher than that of the exchange rate return series. Table 1 also indicate that the asymmetry of the distribution of both the oil and exchange rate series are positively skewed as shown by the standard deviation, meaning that the distribution has a long right tail. The Kurtosis also shows that the distributions of the two series are leptokurtic indicating peaked relative to the normal. The Jarque- Bera test rejects normality in both the oil price and exchange rate returns series. Table 2 also provides further preliminary analyses for the return series.

\subsubsection{Autocorrelation Test}

Table 2 shows the autocorrelation function and reports the Ljung-Box Q-statistic that examines the null hypothesis of no autocorrelation in the series from the estimated result of the Q-statistics for lag lengths of 1, 15, and 36. The results for serial correlation test reveal the presence of serial correlation in the two return series hence, the null hypothesis of no autocorrelation was jointly rejected at the $1 \%$ confidence level for all the three lag length.

Table 2. Autocorrelation test

\begin{tabular}{|c|c|c|c|}
\hline K (lag lenth) & Q-statistics ( $p$-value) & $\mathrm{REXCH}$ & Q-statistics (p-value) ROIL \\
\hline \multirow[t]{2}{*}{1} & 11.668 & & 13.670 \\
\hline & $(0.000)$ & & $(0.000)$ \\
\hline \multirow[t]{2}{*}{15} & 34.799 & & 41.953 \\
\hline & $(0.000)$ & & $(0.000)$ \\
\hline \multirow[t]{2}{*}{36} & 117.27 & & 67.569 \\
\hline & $(0.000)$ & & $(0.000)$ \\
\hline
\end{tabular}

\subsubsection{Unit Root and Simple OLS Regression}

We further conducted the ADF test to determine the null postulate that the series contains a unit root. We use two models - one with a time trend and one that does not have and used the Schwartz information criterion to obtain the optimal lag length. This is the usual process of 


\section{Mll Macrothink}

International Journal of Accounting and Financial Reporting

ISSN 2162-3082

2019, Vol. 9, No. 1

choosing maximum lag hence we select a maximum of 8 lag. The results failed to reject the null hypothesis that the series contain a unit root irrespective of whether the model includes a time trend or not given that the probability values are not significant thus confirming the stationarity of the series.

Table 3. ADF unit root test

\begin{tabular}{llll}
\hline REXCH & \multicolumn{2}{l}{ ROIL } \\
\hline Included trend & No trend & Included trend & No trend \\
\hline$-1.297[1]$ & $1.835[1]$ & $-2.098[1]$ & $-1.038[1]$ \\
\hline
\end{tabular}

We followed up by running OLS regression to estimate the mean equation of our oil price and exchange rate model as specified in equation (3) above. We use the estimated result to test for the presence of $\mathrm{ARCH}$ effect in the residuals and the result of the test is presented in Table 4.

Table 4. OLS model - diagnostic tests

\begin{tabular}{ll}
\hline Diagnostics & OLS \\
\hline ARCH-LM (2) & $\begin{array}{l}4.557 \\
(0.001)\end{array}$ \\
\hline ARCH-LM (4) & 4.009 \\
& $(0.003)$ \\
\hline ARCH-LM (6) & 2.732 \\
& $(0.012)$ \\
\hline ARCH-LM (36) & 1.899 \\
& $(0.001)$ \\
\hline
\end{tabular}

The results of the ARCH LM tests as presented in table 4 indicate the presence of ARCH effects in both series. The obtained P-values from test result were all significant at $1 \%$ confidence level thereby reject the null that the series has no ARCH effect. This means that estimating our model with OLS model would led to spurious result as both the oil and exchange rate returns exhibit conditional heteroscedasticity which has to be captured when modeling the series returns. We thus estimate our mean equation with a model that corrects for the ARCH effect and that model is GARCH and EGARCH, presented in the next section.

\section{The Estimated Model}

$6.1 \operatorname{GARCH}(1,1)$ 
We estimated the $\operatorname{GARCH}(1,1)$ and $\operatorname{GARCH}(1,1)-\mathrm{M}$ models and the results are shown in table v below.

Table 5. GARCH $(1,1)$ model

\begin{tabular}{|c|c|c|}
\hline & GARCH $(1,1)$ & GARCH $(1,1)-\mathrm{M}$ \\
\hline \multicolumn{3}{|l|}{ Mean } \\
\hline$\psi$ & $0.124 * * *$ & $0.081 * * *$ \\
\hline$\theta$ & $-0.162 * * *$ & $-0.0545 * * *$ \\
\hline$\phi$ & $0.101 * * *$ & $0.191 * * *$ \\
\hline$\in$ & & $0.0330 * * *$ \\
\hline \multicolumn{3}{|l|}{ Variance } \\
\hline$\omega$ & $0.940 * * *$ & $0.092 * * *$ \\
\hline$\alpha_{1}$ & $0.459 * * *$ & $0.729 * * *$ \\
\hline$\alpha_{2}$ & $-0.043 * * *$ & $0.017 * * *$ \\
\hline \multicolumn{3}{|l|}{ Diagnostics Tests } \\
\hline \multirow{2}{*}{$Q$-Statistics (1) } & 0.188 & 2.136 \\
\hline & $(0.664)$ & $(0.144)$ \\
\hline \multirow{2}{*}{$Q$-Statistics (15) } & 8.120 & 21.649 \\
\hline & $(0.915)$ & $(0.117)$ \\
\hline \multirow{2}{*}{$Q$-Statistics (36) } & 39.257 & 46.967 \\
\hline & $(0.326)$ & $(0.104)$ \\
\hline \multirow[t]{2}{*}{ ARCH-LM (1) } & 0.024 & 0.001 \\
\hline & $(0.977)$ & $(0.979)$ \\
\hline \multirow[t]{2}{*}{ ARCH-LM (15) } & 0.000 & 0.014 \\
\hline & $(0.998)$ & $(0.569)$ \\
\hline \multirow[t]{2}{*}{ ARCH-LM (36) } & 0.001 & 0.005 \\
\hline & $(0.960)$ & $(0.838)$ \\
\hline
\end{tabular}

Note: $* * *, * *$ and $*$ denote statistical significance at $1 \%, 5 \%$ and $10 \%$ respectively while the $\mathrm{t}$-stat are in parenthesis 


\subsection{EGARCH Model}

Table 6. EGARCH $(1,1)$, and the EGARCH $(1,1)$ - M models

\begin{tabular}{|c|c|c|}
\hline & EGARCH $(1,1)$ & EGARCH $(1,1)-\mathrm{M}$ \\
\hline \multicolumn{3}{|l|}{ Mean Equation } \\
\hline$\psi$ & -0.001 & $-0.076 * * *$ \\
\hline$\theta$ & $-0.001 * * *$ & $0.023 * * *$ \\
\hline$\phi$ & 0.001 & 0.001 \\
\hline$\in$ & - & $0.218 * * *$ \\
\hline \multicolumn{3}{|l|}{ Variance Equation } \\
\hline$\omega$ & $2.729 * * *$ & $-1.001 * * *$ \\
\hline$\alpha$ & 0.599 & $0.114 * * *$ \\
\hline$\gamma$ & -0.067 & $-0.053 * * *$ \\
\hline$\beta$ & $0.750 * * *$ & $-0.544 * * *$ \\
\hline \multicolumn{3}{|l|}{ Diagnostics Tests } \\
\hline \multirow{2}{*}{$Q$-Statistics (1) } & 2.194 & 7.560 \\
\hline & $(0.088)$ & $(0.006)$ \\
\hline \multirow{2}{*}{$Q$-Statistics (15) } & 44.194 & 15.564 \\
\hline & $(0.000)$ & $(0.412)$ \\
\hline \multirow{2}{*}{$Q$-Statisitcs (36) } & 61.114 & 62.693 \\
\hline & $(0.006)$ & $(0.004)$ \\
\hline \multirow[t]{2}{*}{ ARCH-LM (1) } & 0.005 & 0.000 \\
\hline & $(0.828)$ & $(0.158)$ \\
\hline \multirow[t]{2}{*}{ ARCH-LM (15) } & -0.001 & 0.001 \\
\hline & $(0.973)$ & $(0.977)$ \\
\hline \multirow[t]{2}{*}{ ARCH-LM (36) } & 0.000 & 0.001 \\
\hline & $(0.990)$ & $(0.991)$ \\
\hline
\end{tabular}




\section{$\triangle 1$ Macrothink}

International Journal of Accounting and Financial Reporting

ISSN 2162-3082

2019, Vol. 9, No. 1

Note: $* * * * *$ and $*$ denote statistical significance at $1 \%, 5 \%$ and $10 \%$ respectively while the $\mathrm{t}$-stat are in parenthesis

\subsection{Analysis of the Result}

It can be observed from Table 5 that the return estimates are statistically significant in particular; the exchange rate returns shows that previous returns lagged one period have impact on the current exchange rate. The returns in one market affect returns in the other market as any negative shock in the previous period would have a concomitant negative distortion in the current exchange rate. The mean equation of the GARCH $(1,1)$ model, however, indicates that oil price has positive effect on the naira exchange rate. For instance, a rise in oil price returns to the tune of $1 \%$ will cause a rise in the exchange rate by $10 \%$ meaning that the naira will depreciate against the dollar by $10 \%$ all things being equal. The sum of the ARCH and GARCH coefficient term $(0.459+-0.043)$ is 0.42 is less than 1 meaning that shocks to exchange rate volatility is transitory not permanent.

The last column of Table 5 shows the result of the GARCH $(1,1)-\mathrm{M}$ model. Here also, both the mean and the variance are statistically significant at $1 \%$ confidence level. This indicates that the lagged naira exchange rate movement has impact on the current rate. The mean and variance equation in the $\mathrm{ARCH}$ and $\mathrm{GARCH}$ terms are also found to be statistically significant and similar to the GARCH $(1,1)$ model in column 2, the oil prices shock have a positive influence on naira exchange rate.

The results presented in columns 2 and 3 of table 6 for the $\operatorname{EGARCH}(1,1)$ and EGARCH-M shows that exchange rate in the previous period affect itself and the coefficient is statistically significant at $1 \%$ confidence level. On the other hand, a rise in oil price return affects the exchange rate of the Naira/dollar rate in a positive way however, the coefficient is not statistically significant hence of no effect.. The asymmetric test represented by the variance equation and denoted by the gamma is also positive and significant at $5 \%$ level. This signify that a positive change in oil prices have higher impact on volatility of exchange rates than the negative shocks of the same magnitude. Similarly, volatility persistent term is denoted by the beta and is significant at $1 \%$ confidence level in the two models. The summation of the coefficients of 0.114 and -0.045 respectively is also less than 1 thus suggesting that shocks to exchange rate volatility has temporary effects.

\subsection{Post Estimation Test}

We finally, conducted post estimation diagnostics test on the residual of our GARCH and EGARCH models. This includes Engle ARCH and Ljung-Box Q-statistic test for autocorrelation. The results are tabulated in the final panel of table 5 and 6 . The Ljung-Box Q-statistics which computes the various lag level did not show evidence of serial correlation hence we failed to reject the null hypothesis of no autocorrelation in the return series. The ARCH-LM test also indicates the absence of remaining ARCH effects in the return series. In conclusion the diagnostics are quite satisfactory and the model well behaved and confirms the validity of the estimated results.

\section{Discussion of Results and Conclusion}




\section{Mll Macrothink}

International Journal of Accounting and Financial Reporting

ISSN 2162-3082

2019, Vol. 9, No. 1

The result obtained from our estimation is consistent with our postulation that Nigeria's economy substantially depends on oil income and therefore any shock in the prices of oil at the international oil market would significantly affects its revenue receipt and by extension the macro economy. This is not surprising given that Nigeria is a net exporter of oil, thus its concentration on oil as the main activity has brought the 'Dutch Disease' syndrome on Nigeria. The discovery of oil wealth has led to the neglect of other key sectors of the economy particularly agriculture and manufacturing which started gradually and later replaced with oil as the main revenue source. Similarly, the obsession of Nigerians towards consumption of foreign goods and fashion along with genuine demand for the settlement of imported machineries, chemicals, the debt servicing, and other demand such as airline remittance, foreign dividend payment, education and medical tourism contributed to the demand for foreign exchange in the country. This makes difficult for the monetary authorities to manage the exchange rate market thus infringing on its ability to build a strong foreign reserves.

Also, demand pressure for foreign exchange often heightened activities at the parallel market thereby making the naira to depreciate against other currencies especially the dollar. In response to these challenges, the current government introduced policies that would diversify the country's export away from oil. Development initiatives are now focused on the non-oil sector such as mining and agriculture in order to permanently address the impact of oil shock on the Nigerian economy particularly during oil price downturn. To this end, Government has control import by increasing tariffs and duties and on its part, the monetary authority has prohibited 53 items (rice, steel, palm oil, furniture, and woven item) among others from accessing foreign exchange through the official CBN window because Nigeria has the capacity to produce them locally. The monetary authorities is supporting the current fiscal drive towards economic diversification by enhancing its developmental mandate through various programs that support agriculture, manufacturing and other critical sectors of the economy.

\subsection{Concluding Remark}

This study contributes to the imperative of using a time series generalized auto regressive conditional heteroscedasticity in the Mean GARCH $(1,1)$-Mean and EGARCH models to examine the causal link between oil prices and the nominal naira exchange rate in Nigeria model. The study utilized daily time series data from 12/07/2010 - 31/08/2017. First, we tested for the presence of stationarity in each of the return series. This was followed by a test for the presence of ARCH effects. We proceeded with our analysis due to the absence of stationarity and ARCH effects in the return series. We finally, conducted post estimation diagnostics test on the residual of our GARCH and EGARCH models. This includes Engle ARCH and Ljung-Box Q-statistic test for autocorrelation which computes the various lag level did not show evidence of serial correlation hence we failed to reject the null hypothesis of no autocorrelation in the return series.

Our general finding shows that an increase in oil price causes local currency (naira) to appreciate while a fall in the price of oil significantly affects the value of the naira by causing it to depreciate in relation to the US dollar. This confirms our a-priori expectation given 


\section{Mll Macrothink}

International Journal of Accounting and Financial Reporting

ISSN 2162-3082

2019, Vol. 9, No. 1

Nigeria dependence on oil revenue. Therefore any shock in the prices of oil at the international oil market would significantly affects its overall economy. This perhaps explains government renewed interest towards the development of the non-oil sector including mining and agriculture in order to stem the Nigeria economy from the caprices of international crude oil market.

\section{References}

Afees, S. A., \& Mobolaji, H. (2013). Modeling returns and volatility transmission between oil price and US - Nigeria rate. Energy Economics, 39, 169-176.

Akram, Q. F. (2002). Oil prices and exchange rates: Norwegian evidence. Research Department, Norges Bank

Arouri, M., Bellalah, M., \& Nguyen, D. K. (2011). Further Evidence on the Response of Stock Prices in GCC Countries to Oil Price Shocks. International Journal of Business, 16.

Arouri, M., Jouini, J., \& Nguyen, D. K. (2012). On The Impact Of Oil Price Fluctuations On European Equity Markets: Volatility Spillover And Hedging Effectiveness. Energy Economics, 34, 11-617.

Beckmann, J., Czudaj, R., \& Arora, V. (2017). The Relationship between Oil Prices and Exchange Rates: Theory and Evidence. Working Paper Series.

Bollerslev, T. (1986). Generalised autoregressive conditional heteroskedasticity. Journal of Econometrics, 31, 307-327.

Bollerslev, T., \& Wooldridge, J. M. (1992). Quasi-maximum likelihood estimation and inference in dynamic models with time varying covariances. Econometric Reviews, 11, 143-172.

Boyer, M. M., \& Filion, D. (2007). Common and Fundamental Factors in Stock Returns of Canadian Oil and Gas Companies. Energy Economics, 29, 428-453.

Cologni, A., \& Manera, M. (2008). Oil Prices, Inflation and Interest Rates in a Structural Cointegrated VAR Model for the G-7 Countries. Energy Economics, 30, 856-888.

Cunado, J., \& de Garcia, F. P. (2005). Oil Prices, Economic Activity and Inflation: Evidence for Some Asian Countries. Quarterly Review of Economics and Finance, 45, 65-83.

Darby, M. R. (1982). The price of oil, world inflation, and recession. The American Economic Review, (72), 738-751.

El-Sharif, I., Brown, D., Burton, B., Nixon, B., \& Russel, A. (2005). Evidence on the Nature and Extent of the Relationship between Oil and Equity Value in UK. Energy Economics, 27, 819-830.

Engle, R. F. (2002). Dynamic Conditional Correlation: A Simple Class of Multivariate GARCH Models. Journal of Business and Economic Statistics, 20, 339-350.

Engle, R. F., \& Kroner, K. F. (1995). Multivariate Simultaneous Generalized ARCH. Econometric Theory, 11, 122-150. 


\section{$\triangle 1$ Macrothink}

International Journal of Accounting and Financial Reporting ISSN 2162-3082

Fratzscher, M. (2014, July). Oil Prices, Exchange Rates and Asset Prices. ECB Working Paper Series, No. 1689.

Gisser, M., \& Goodwin, T. H. (1986). Crude Oil and the Macro economy: Tests of Some Popular Notions: Note. Journal of Money, Credit and Banking, 18(1), 95-103.

Hamilton, J. D. (1983). Oil and the Macroeconomy since World War II. The Journal of Political Economy, 91(2), 228-248.

Hamilton, J. D. (2003). What is an Oil Shock?. Journal of Econometrics, 113, 363-398.

Hamisu, S. A. et al (2015). Dynamic relationship of exchange rates and crude oil prices in South Africa: Are there asymmetries?. Research Journal of Finance and Accounting, 6(6).

Hooker, M. A. (1996). What Happened To The Oil Price-Macroeconomy Relationship?. Journal of Monetary Economics, 38, 195-213.

Huang, R. D., Masulis, R. W., \& Stoll. H. R. (1996). Energy Shocks and Financial Markets. Journal of Futures Markets, 16, 1-27.

Jones, C. M., \& Kaul, G. (1996). Oil and the Stock Markets. Journal of Finance, 51(2), 463-491.

Kaushik, N., Nag, R., \& Upadhyaya, K. P. (2014). Oil Price and Real Exchange Rate: The Case of India. International Business \& Economics Research Journal, 13(4).

Kilian, L. (2008). Exogenous Oil Supply Shocks: How Big Are They and How Much Do They Matter for the US Economy?. Review of Economics and Statistics, 90, 216-240.

Kim, J., \& Jung, H. (2018). Relationship between oil price and exchange rate by FDA and Copula. Journal Applied Economics, 50(22).

Kin, S., \& Courage, M. (2014). The Impact of Oil Prices on the Exchange Rate in South Africa. Journal of Economics, 5(2), 193-199.

Malik, F., \& Hammoudeh, S. (2005). Shock and Volatility Transmission in the Oil, US and Gulf Equity Markets. International Review of Economics and Finance, 16, 357-368.

Mensah, M., Awunyo-Victor, D., \& Asare, M. H. (2013). Exchange Rate Volatility and Employment Growth in Ghana's Manufacturing Sector. International Journal of Business and Social Science, 4(4).

Mork, K. A. (1989). Oil and the Macroeconomy When Prices Go Up And Down: An Extension of Hamilton's Results. Journal of Political Economy, 97(3), 740-744.

Narayan, P. K., Narayan, S., \& Prasad, A. (2008). Understanding the Oil Price-Exchange Rate Nexus for the Fiji Island. Energy Economics, 30(2686-2696).

Nelson, D. (1991). Conditional Heteroskedasticity in Asset Return: a new approach. Econometrica, 59, 347-370.

Ogundipe, O. M., Ojeaga, P., \& Ogundipe, A. A. (2014). IOSR. Journal of Economics and Finance, 5(4), 01-09. 


\section{Macrothink}

International Journal of Accounting and Financial Reporting

ISSN 2162-3082 2019, Vol. 9, No. 1

Oriavwote, V. E., \& Eriemo, N. O. (2012). Oil Prices and the Real Exchange Rate in Nigeria. International Journal of Economics and Finance, 4(6).

Park, J., \& Ratti, R. A. (2008). Oil Price Shocks and Stock Markets in the US and 13 European Countries. Energy Economics, 30(2587-2608).

Ramaprasad, B., \& Nikolova, B. (2009). Oil Prices and Equity Returns in the BRIC Countries. World Economy, 32(7), 1036-1054.

Rentschler, J. E. (2013). Oil Price Volatility, Economic Growth and the Hedging Role of Renewable Energies. Policy Research Working Paper 6603, World Bank, Washington, DC

Sadorsky, P. (1999). Oil Price Shocks and Stock Market Activity. Energy Economics, 21, 449.

Schwartz, G. (1978). Estimating the dimensions of the model. Annals of Statistics, 6, 461-464.

Zhang, Y. (2013). The Links between the Price of Oil and the Value of US Dollar. International Journal of Energy Economics and Policy, 3(4), 341-351.

\section{Copyright Disclaimer}

Copyright for this article is retained by the author(s), with first publication rights granted to the journal.

This is an open-access article distributed under the terms and conditions of the Creative Commons Attribution license (http://creativecommons.org/licenses/by/4.0/) 